\title{
Informationen für die Klinik/Clinical Information
}

Neues zu TNM/Konsiliartätigkeit des DSK

Seit 1987 gilt zur Klassifikation der anatomi-schen Tumorausbreitung die 4. Auflage der TNMKlassifikation. Neben der deutschen Übersetzung des TNM-Taschenbuches (TNMKlassifikation maligner Tumoren, 4. Aufl. Berlin, Springer, 1987) wird in Kürze auch die 2. deutsche Auflage des TNM-Atlas (UICC: TNM-Atlas. Illustrierter Leit-faden zur TNM/pTNMKlassifikation maligner Tumoren. 2. Aufl. Berlin, Springer, 1989) verfügbar sein. Ihm ist als heraus-nehmbare Beilage eine Zusammenstellung der Kurzfassungen der Definitionen von Tund N-Kategorien beigegeben, die zur Verwendung als jederzeit mitnehmbare Ge-dächtnisstütze gedacht ist. Bei der Verwendung des TNM-Systems wird es derzeit immer noch notwendig sein, fall-weise die 3. Auflage zu verwenden, da für zurückliegende Patienten eine Klassifikation nach der 4. Auflage oft nicht möglich ist. Um hieraus entstehende Mißverständ-nisse und Unklarheiten zu vermeiden, bittet das DSK alle Kollegen, bei Vorträgen und Publikationen stets anzugeben, ob die be-richtigte TNM-Klassifikation nach der 3. oder 4. Auflage erfolgt ist. Wenngleich bei der Herausgabe der 4. Auflage der TNM-Klassifikation auf möglichst eindeutige Definitionen besonders geachtet wurde, ergeben sich doch immer wieder Fragen und Unklarheiten. Hierfür steht das DSK jederzeit zur Auskunft bereit. Anfra-gen sind am besten an den Sekretär des DSK, Herrn Prof. Dr. Burg, Univ.-Klinik und Poliklinik für Haut- und Geschlechts-krankheiten, Josef-Schneider-Straße 2, D-8700 Würzburg, zu richten. Das TNM Project Committee der UICC und das DSK sind an einer möglichst weitge-streuten Testung der 4. Auflage des TNM-Systems interessiert. Das gilt sowohl für den Vergleich der Ergebnisse klinischer Klassifikation (mit verschiedenen Methoden) mit jenen der pathologischen Klassifikation als auch für die Beurteilung der Prognose in Abhängigkeit von TNM/pTNM und Stadium. Besonders begrüßt werden Vergleiche der 4. Auflage mit der früheren 3. Auflage. Großes Interesse besteht auch an der Wei-terentwicklung des Systems, die in den nächsten 8-10 Jahren mittels der sog. Ramifikation erfolgen soil. Hierbei können bestimmte T-, N- oder MKategorien, von denen vermutet wird, daß sie prognostisch nicht homogen sind, in Unterkategorien un-terteilt werden, um so etwaige Unterschiede in der Prognose zu erfassen. So kann z. B. beim Kolon- und Rektumkarzinom die Ka-tegorie pT3 (Infiltration der Subserosa bzw. des perikolischen/perirektalen Gewebes) nach dem Ausmaß der Infiltration, gemessen am histologischen Schnitt, in zwei oder drei Unterkategorien (pT3a, b, c) unterteilt werden. Das DSK bittet alle Kollegen, entsprechen-de Untersuchungen oder auch Vorschläge hierzu mitzuteilen, damit sie an die UICC nach Genf zur zentralen Bearbeitung weitergeleitet werden können.

\section{Ondansetron}

Ondansetron is a selective serotonin 5HT3-antagonist, one of the first drugs of this type to be synthesized. It has been developed by Glaxo initially for use as an anti-emetic agent specifically for use against chemotherapy- and radiotherapy-induced nausea and vomiting. To date, ondansetron has been studied in 223 healthy volunteers and in 1,423 cancer patients undergoing chemotherapy or radiation treatment. Ondansetron is also under investigation for a 
number of other indications, including psychiatric disorders, and to date a further 438 patients have received the drug.

From this large data bank, the evidence of the safety of ondansetron is reassuring, according to Dr Robert Smith, director of medical affairs at Glaxo Group Research. Side-effects appear to be limited to constipation and headache. Constipation was the commonest complaint among both volunteers (reported by $3 \%$ ) and patients ( $7 \%-16 \%)$, and seems to be a real effect of the drug, as 5HT3-receptors are found in the gastro-intestinal tract, and ondansetron has been shown to prolong colonic transit time. Headache was reported most frequently by patients in non-emesis studies (13\%), especially in those with psychiatric disorders. Other effects include a warm sensation and flushing on intravenous administration of the drug, but this is a 'minor problem', Dr. Smith comments. In addition, some diarrhea was reported with ondansetron, but this may be caused by chemotherapy. Raised liver enzymes have been observed, but experience from all the human studies has not revealed any association with clinical symptoms or signs (e.g. jaundice). It appears that the elevations are transient and reversible.

Perhaps most encouraging of all, no ex-trapyramidal symptoms have been observed with ondansetron.

The absence of extrapyramidal side-effects, coupled with the superior anti-emetic efficacy of ondansetron compared with the best of available agents, led a number of authors to suggest that the new drug represents an important advance in the treatment of chemotherapy- and radiotherapy-induced emesis. Professor Schmoll, Hannover, has declared ondansetron to be a 'major step foward' in the treatment of cancer patients. Ondansetron is currently awaiting registration in the UK and a number of other countries. A UK product licence application was filed in April 1989, and filings in other countries followed shortly afterwards. At present, Glaxo appears to be ahead of other companies that are developing similar compounds, so ondansetron is likely to be the first drug of its type to be commercially available.

Preisverleihung

Verleihung des

VINZENZ-CZERNY-PREISES 1989 an Mainzer Wissenschaftler

Die Auszeichnung der Deutschen Gesell-schaft für Hämatologie und Onkologie wurde jetzt an einen Wissenschaftler der Johannes Gutenberg-Universität Mainz vergeben. Dr. med. Thomas Wolf el, wissenschaftlicher Mitarbeiter der I. Medizinischen Klinik und Poliklinik (Leitung: Professor Dr. Dr. K. H. Meyer zum Büschenfelde) erhielt den Vinzenz-Czerny-Preis 1989 für seine Arbeit «Autologe Zytotoxizität gegen menschliche Tumorzellen: Multiple CTL-defínierte Tumorantigene und Bedeutung von HLA-Molekülen der Klasse I für die Tumorzell-erkennung». Der Preis wird jährlich von der Lilly Deutschland GmbH, Bad Homburg v. d. Höhe, gestiftet und ist mit DM 10000,-dotiert.

D. Der Preis wurde anläßlich der Jahrestagung der Deutschen Gesellschaft für Hämatologie und Onkologie in Hannover von Professor Dr. med. van de Loo

Medizi-nische Klinik der Universität Münster

überreicht

der auch die Laudatio hielt. 